\title{
EXPERIMENTAL INVESTIGATION ON PARTIAL REPLACEMENT OF CEMENT BY SAW DUST ASH AND POLY PROPYLENE FIBRE
}

\author{
Jeron.R ${ }^{1}$, Akash.Thomas.Chacko ${ }^{2}$, Ashlin.Tom.Varghese ${ }^{3}$, Cyril.Simon ${ }^{4}$ \\ ${ }^{1}$ Assistant Professor, Department of Civil Engineering, Mar Ephraem College of Engineering and Technology, \\ Elavuvilai, India \\ ${ }^{2} U G$ Student, Mar Ephraem College of Engineering, Elavuvilai, India \\ ${ }^{3} U G$ Student, Mar Ephraem College of Engineering, Elavuvilai, India \\ ${ }^{4} U G$ Student, Mar Ephraem College of Engineering, Elavuvilai, India
}

\begin{abstract}
Theaim of this project is to study the strength and durability of concrete when cement is partially replaced by saw dust ash and poly propylene fiber. The attempt has been made to compare the 7 day, 14 day and 28 day compressive strength and 28 day split tensile and flexural strength of concrete of $M_{25}$ grade. The experiment has been carried out on $M_{25}$ grade of concrete, wood ash in different percentage $0 \%, 5 \%, 10 \%, 15 \%$ and poly propylene $0.15 \%$.
\end{abstract}

Keywords - specific gravity, compressive strength, poly propylene fibre, wood ash, cement content, concrete testing.

\section{INTRODUCTION}

The wastes generated from the biomass industries like sawdust, wood chips, wood barks and hard chips are increasing day by day. This wastes can be used as fuel for the safe and efficient disposal of this wastes. Modern technologies are now available for production of the saw dust ash in bulk quantities. The saw dust ash is used as partial replacement of cement inorder to give high strength and crack resistance. The production of cement results in emission of green house gases and other pollutants. Hence the replacement of saw dust ash by cement contribute to less production of cement and make environment safe. The usage of saw dust ash helps in efficient disposal of waste generated and also a partial replacement of cement. Researches carried out shows positive result for saw dust ash in cement. So the usage of this wastes are beneficial in both economically and environmentally.

\section{OBJECTIVE}

The objective of this study is to find the optimum strength by the mix ratio of cement, saw dust ash, aggregates, poly propylene fiber, and water.

\section{COMPONENT MATERIALS}

\subsection{Cement}

Cement is a binding material used in the preparation of concrete. It binds the coarse aggregates and fine aggregates with help of water, to a monolithic matter and also it fills the voids in the concrete.

\subsection{Aggregates}

The fine aggregates used in the manufacturing of concrete should be free from debris, fungi and chemical attack. It plays a vital role in concrete, so it should be durable, angular and sharp edges. Then only it gives a rich mix concrete and good workability.

\subsection{Water}

Water is an important ingredient of concrete as it actively participate in the chemical reactions with cement. The strength of cement concrete mainly from binding action of the hydration of cement get the requirement of water should be reduced to that required chemical reaction of un-hydrated cement as the excess water should end up in only formation undesirable voids or capillaries in the hardened cement paste in concrete.

\subsection{Saw Dust Ash}

Saw dust ash prepared from uncontrolled burning of sawdust from saw mill is studied for its suitability as partial replacement for cement in conventional concrete. The compressive strength, split tensile and flexural strength of concrete with blended wood ash cement are carefully studied. Water-to-binder ratio is taken as 0.4 and three different replacement percentages of wood ash is taken $(5 \%, 10 \%$ and $15 \%)$.

\subsection{Poly Propylene Fiber}

Poly propylene fiber is a thermoplastic polymer, now it is widely used in various application such as textiles, packaging, concrete mix etc. The raw material of raw material of poly propylene is derived from monomeric 
C3H6 which is purely carbon in nature. Due to chemical inertness, fiber is mostly resistant to chemical attack hence chemical attack on concrete will not affected by fiber. Also water demand is nil for the fiber. Poly propylene fiber resist crack formation on the concrete surface.

\section{RESULT COMPARISON}

\subsection{Compressive Strength Test on Concrete}

\begin{tabular}{|c|c|c|c|c|c|}
\hline \multirow{2}{*}{$\begin{array}{l}\text { Additi } \\
\text { on of } \\
\text { saw } \\
\text { dust } \\
\text { ash\% }\end{array}$} & \multirow{2}{*}{$\begin{array}{l}\text { No. of } \\
\text { days } \\
\text { of } \\
\text { curin } \\
\text { g }\end{array}$} & \multicolumn{3}{|c|}{$\begin{array}{l}\text { Load Applied } \\
(\mathrm{kN})\end{array}$} & \multirow{2}{*}{$\begin{array}{l}\text { Average } \\
\text { Compressi } \\
\text { ve } \\
\text { Strength } \\
\text { N/mm }\end{array}$} \\
\hline & & $\begin{array}{l}\mathrm{Cu} \\
\text { be } \\
\mathbf{1}\end{array}$ & $\begin{array}{l}\mathrm{Cu} \\
\text { be } 2\end{array}$ & $\begin{array}{l}\mathrm{Cu} \\
\text { be } 3\end{array}$ & \\
\hline 5 & 7 & 450 & 400 & 430 & 18.96 \\
\hline 10 & 7 & 370 & 340 & 320 & 15.25 \\
\hline 15 & 7 & 200 & 200 & 220 & 9.18 \\
\hline
\end{tabular}

\begin{tabular}{|c|c|c|c|c|c|}
\hline \multirow{2}{*}{$\begin{array}{l}\text { Additi } \\
\text { on of } \\
\text { saw } \\
\text { dust } \\
\text { ash\% }\end{array}$} & \multirow{2}{*}{$\begin{array}{l}\text { No. of } \\
\text { days } \\
\text { of } \\
\text { curin } \\
\text { g }\end{array}$} & \multicolumn{3}{|c|}{$\begin{array}{l}\text { Load Applied } \\
(\mathbf{k N})\end{array}$} & \multirow{2}{*}{$\begin{array}{l}\text { Average } \\
\text { Compressi } \\
\text { ve } \\
\text { Strength } \\
\text { N/mm }\end{array}$} \\
\hline & & $\begin{array}{l}\mathrm{Cu} \\
\text { be } \\
\mathbf{1}\end{array}$ & $\begin{array}{l}\mathrm{Cu} \\
\text { be } 2\end{array}$ & $\begin{array}{l}\mathrm{Cu} \\
\text { be } 3\end{array}$ & \\
\hline 5 & 14 & 550 & 570 & 550 & 24.74 \\
\hline 10 & 14 & 350 & 370 & 340 & 15.70 \\
\hline 15 & 14 & 250 & 300 & 240 & 11.70 \\
\hline
\end{tabular}

\begin{tabular}{|c|c|c|c|c|c|}
\hline \multirow{2}{*}{$\begin{array}{l}\text { Additi } \\
\text { on of } \\
\text { saw } \\
\text { dust } \\
\text { ash\% }\end{array}$} & \multirow{2}{*}{$\begin{array}{l}\text { No. of } \\
\text { days } \\
\text { of } \\
\text { curin } \\
\text { g }\end{array}$} & \multicolumn{3}{|c|}{$\begin{array}{l}\text { Load Applied } \\
(\mathbf{k N})\end{array}$} & \multirow{2}{*}{$\begin{array}{l}\text { Average } \\
\text { Compressi } \\
\text { ve } \\
\text { Strength } \\
\text { N/mm }\end{array}$} \\
\hline & & $\begin{array}{l}\mathrm{Cu} \\
\text { be } \\
1\end{array}$ & $\begin{array}{l}\mathrm{Cu} \\
\text { be } 2\end{array}$ & $\begin{array}{l}\mathrm{Cu} \\
\text { be } 3\end{array}$ & \\
\hline 5 & 28 & 600 & 650 & 630 & 27.85 \\
\hline 10 & 28 & 420 & 450 & 400 & 18.81 \\
\hline 15 & 28 & 390 & 350 & 370 & 16.44 \\
\hline
\end{tabular}

\subsection{Split Tensile Test on Concrete}

\begin{tabular}{|c|c|c|c|c|c|}
\hline \multirow{2}{*}{$\begin{array}{l}\text { Additi } \\
\text { on of } \\
\text { saw } \\
\text { dust } \\
\text { ash\% } \\
\end{array}$} & \multirow{2}{*}{$\begin{array}{l}\text { No. of } \\
\text { days } \\
\text { of } \\
\text { curin } \\
\text { g } \\
\end{array}$} & \multicolumn{3}{|c|}{$\begin{array}{l}\text { Load Applied } \\
(\mathbf{k N})\end{array}$} & \multirow{2}{*}{$\begin{array}{l}\text { Average } \\
\text { Split } \\
\text { Tensile } \\
\text { Strength } \\
\text { N/mm } \\
\end{array}$} \\
\hline & & $\begin{array}{l}\text { Tri } \\
\text { al } 1 \\
\end{array}$ & $\begin{array}{l}\text { Tri } \\
\text { al } 2 \\
\end{array}$ & $\begin{array}{l}\text { Tri } \\
\text { al3 } \\
\end{array}$ & \\
\hline 0 & 28 & 200 & 180 & 210 & 2.78 \\
\hline 5 & 28 & 225 & 230 & 220 & 3.18 \\
\hline 10 & 28 & 170 & 165 & 165 & 2.4 \\
\hline 15 & 28 & 160 & 155 & 160 & 2.23 \\
\hline
\end{tabular}

\subsection{Flexural Strength Test on Concrete}

\begin{tabular}{|c|c|c|c|c|c|}
\hline \multirow{2}{*}{$\begin{array}{l}\text { Additi } \\
\text { on of } \\
\text { saw } \\
\text { dust } \\
\text { ash\% }\end{array}$} & \multirow{2}{*}{$\begin{array}{l}\text { No. of } \\
\text { days } \\
\text { of } \\
\text { curin } \\
\text { g }\end{array}$} & \multicolumn{3}{|c|}{$\begin{array}{l}\text { Load Applied } \\
(\mathbf{k N})\end{array}$} & \multirow{2}{*}{$\begin{array}{l}\text { Average } \\
\text { Flexural } \\
\text { Strength } \\
\mathrm{N} / \mathrm{mm}^{2}\end{array}$} \\
\hline & & $\begin{array}{l}\text { trial } \\
1\end{array}$ & $\begin{array}{l}\text { trial } \\
2\end{array}$ & $\begin{array}{l}\text { tr } \\
\text { ail } \\
3\end{array}$ & \\
\hline 0 & 28 & 20.5 & 20.5 & 20 & 10.16 \\
\hline
\end{tabular}

\begin{tabular}{|l|l|l|l|l|l|}
\hline 5 & 28 & 22.5 & 23 & 23 & 11.41 \\
\hline 10 & 28 & 17 & 17.5 & $\begin{array}{l}18 \\
.1\end{array}$ & 9.1 \\
\hline 15 & 28 & 17 & 18 & 18 & 8.83 \\
\hline
\end{tabular}

\section{CONCLUSION}

The main purpose of this investigation is to study the effects of saw dust ash and poly propylene fiber on the workability, compressive strength, split tensile and flexural strength of $\mathrm{M}_{25}$ grade concrete.

For comparison, reference specimens were tested without saw dust ash and poly propylene fiber.

Experimental results show that the workability of concrete reduces with addition of poly propylene fiber in concrete and also the results show that the poly propylene fiber concrete specimens gives higher compressive, split tensile and flexural strength than the ordinary concrete specimens.

The highest strength has been achieved in samples containing $5 \%$ wood ash and $0.4 \%$ poly propylene fiber.

Based on the results presented in this paper, it can be concluded that concrete mixture can be prepared with saw dust ash as an additive together with poly propylene fiber to improve the strength of concrete structure.

\section{REFERENCES}

[1] Bramryd T , Frashman B. silvicultural use of wood ashes-effects on the nutrient and heavy metal balance in a pine (pinus sylvestris, L) forest soil. In: Water, Air and soil pollution proceeding of the $19955^{\text {th }}$ international conference on Acidic Deposition: science and policy Acid Regin '95,part II vol .85. (2) Dordrecht, Netherland: Kluwer academic publisher;1995.p.1039-44

[2] Naik TR Test of wood ash as a potential source for construction materials. Report No. CBU-199609.Milwaukee;UWM Centre for By-product utilization ,Department of Civil Engineering and Mechanics ,university of Milwaukee ; 1999.p.61

[3] M. Grybowski, S.P Shah Shrinkage cracking of fiber reinforced concrete, ACI Material journal (1990(March-April) $138-148$

[4] N Banthia, M Azzabi, M Pageon, Restrained shrinkage cracking in fiber reinforced cementitious composites, Materials and Structures RILEM (Paris) 26 (161)(1993)405-413

[5] Fehrs JE.Ash from the combustion of treated wood : characterization and management options In presented at the National Bio ash Utilization Conference ; 1996 p.2

[6] Nguyen p, pascal KD Application of wood ash forestland ;ecosystem response and limitation In ; proceeding of the conference on Eastern Hardwoods Resources, Technologies and market, forest product society ; 1997.p203 
[7] R.Bloom A. Bentur ,Free and restrained shrinkage of normal and high strength concrete,ACI Materials journal 92 (2) (1995).

[8] A.Khajuria , $\mathbf{P}$ Balaguru Plastic shrinkage characteristics of fiber reinforced cement composites, in : R.N Swami (Ed.), Fiber Reinforced Cement and Concrete ,E\&FN Spon ,London, 1992, pp. 82-90 